\title{
The Crisis of US Coal Communities: Strategies for a Just Transition to Renewable Energy
}

\author{
Grace E. Chesmore ${ }^{1}$, Rachel L. Starr $^{2}$, Rebecca Van Hoeck ${ }^{3}$, \\ Meredith L. Ward \\ 1University of Chicago, Physics Department, Chicago, IL \\ ${ }^{2}$ Columbia University, Chemistry Department, New York City, NY \\ ${ }^{3}$ University of North Carolina, Biology Department, Chapel Hill, NC \\ https://doi.org/10.38126/ISPG180202 \\ Corresponding author: chesmore@uchicago.edu \\ Keywords: just transition; land reclamation; job retraining; economic relief; coal power; renewable energy
}

Executive Summary: Though coal was once a leading source of energy and economic growth, negative health impacts, detrimental environmental effects, and market forces have led to a rapid decline in production. Without nationwide legislation aiding them, coal-dependent communities in the US are suffering from financial downfall during this shift. Here, we propose three policy options to uplift these communities by providing subsidies to renewable energy companies that expand operations in former coal communities, reclaim the land, and provide job retraining. These options, alongside suggested federal funding for direct community aid, work cohesively to provide a lasting source of economic stability, improve environmental and public health in former coal-dependent communities, and mitigate the climate crisis. We call upon the Interagency Working Group on Coal and Power Plant Communities and Economic Revitalization (Interagency Working Group) to ensure the diversion of subsidies away from the coal industry and towards these efforts to promote a just transition for the affected communities.

\section{The crisis of coal communities}

Over the last decade, US coal production has rapidly declined. Over 300 coal-fired power plants have been retired (Palacios 2020), and more than $42 \%$ of jobs in coal production have been lost since 2011, mostly concentrated in the Appalachian region (Fritsch 2019). Without proper support during the phase-out of coal, coal-reliant communities suffer from negative economic consequences. Moreover, the economic fallout of coal mine and plant closures extends far beyond coal-adjacent jobs. In Boone County, WV, coal plant closures led to bankruptcies, layoffs, and mass relocation. The loss in county revenues subsequently led to county employee and teacher layoffs as well as benefit reductions (Skibell 2020). The closure of two coal-fired power plants in Appalachian Ohio resulted in the loss of over 1,100 jobs and $\$ 8.5$ million in budget reductions for the county, school districts, and social services due to lost tax revenue paid by the plant (Jolley et al. 2019).
The hardships faced in the wake of coal job losses are exacerbated by the lack of other industry or manufacturing jobs (Humphreys et al. 2014). Additionally, former coal workers may be forced into new, and lower-earning professions (Sainato 2020; Milman 2020). It is therefore imperative that sustainable and local job options be made available to former miners. As of 2016, retraining the remaining 60,000 US coal workers would cost at most $\$ 1.8$ billion, only $0.0543 \%$ of the federal budget (Louie and Pearce 2016). With today's remaining 45,000 coal mining jobs, fully transitioning former miners to clean energy positions would require an even smaller investment in retraining (Milman 2020). Moreover, training costs are far surpassed by the potential cost of harmful coal-associated externalities, including reduction in life expectancy, degradation and soiling of buildings, and ecosystem loss, which could add up 
to approximately $\$ 420$ billion annually (Louie and Pearce 2016).

Coal extraction and processing is damaging to the environmental and public health of the surrounding community. Low-income communities and communities of color are disproportionately affected, with approximately $68 \%$ of Black Americans living within 30 miles of a coal plant (Haynes 2012). In the Navajo Nation, the use of groundwater for coal transport has drained the local aquifer; consequently, residents have to drive to community water stations for access to water (Vanderpool 2020). Additionally, a spill at the abandoned Gold King Mine in 2015 contaminated waterways with heavy metals in the Navajo Nation and three states (EPA 2015; O'Donoghue 2020). Land reclamation, which aims to restore abandoned sites to their natural states, could address these health and financial burdens. With an estimated 500,000 abandoned hard rock mining sites on federal lands according to the EPA, this crisis needs to be addressed before a greater population is impacted (O’Donoghue 2020).

\section{Current US response}

Coal-dependent communities need support during this transition, but there is no cohesive nationwide plan to justly phase out coal. Many state-level policies that aim to accelerate this phase-out while achieving renewable energy targets often ignore the financial burden for affected coal-dependent communities (California Energy Commission 2020; Anderson 2007 43; Beyer 2016). In an attempt to fill this gap, President Obama launched the Partnerships for Opportunity and Workforce and Economic Revitalization Plus Plan (POWER+) in 2015 to financially uplift affected communities (Cecire 2019). Unfortunately, many components were never enacted because the plan only received partial funding for Fiscal Year 2016. Some aspects of this initiative persist, including funding for abandoned mine land reclamation and assistance to coal communities within the Economic Development Administration (Cecire 2019).

While the Trump administration attempted to deregulate the coal industry to increase production, competition from natural gas continued to eclipse coal production (Dennis 2019; Gross 2020). In 2017, the Trump administration converted the funded aspects of POWER+ into the Economic Adjustment
Assistance program, and Congress appropriated $\$ 30$ million for Assistance to Coal Communities (ACC). The majority of funds went to job retraining in manufacturing fields and job creation through infrastructure development, but the plan was insufficient to replace job losses and no funds went towards transitioning to renewable energy (Economic Development Administration 2017). For example, in Randolph County, WV, over 10,000 coalrelated jobs were lost from 2009-2017, and a $\$ 2.5$ million federal investment from the ACC only created 50 new jobs in existing manufacturing fields. By not supporting new industries, attempts to increase coal production have exacerbated the economic vulnerability of coal communities and discouraged abandoned mine reclamation. Although several pieces of federal legislation have been proposed since 2017 to aid coal communities (Cartwright 2021; Duckworth 2020; Neal 2020; Grijalva 2020; Grijalva 2021; McConnell 2017), most never made it out of committee, and others have had to be reintroduced due to expiration from lack of action in previous Congresses.

The Biden administration plans to prioritize climate change and support for coal-dependent communities. On January 27, 2021, an executive order established the Interagency Working Group, which will use policy-making and budget processes to address climate change (White House 2021). This executive order also aims to create jobs through abandoned mine land reclamation and achieve a carbon pollution-free electricity sector by 2035 (White House 2021).

\section{Policy options}

The realities of the climate crisis make it imperative to phase out coal; however, the US policy response has insufficiently supported coal-reliant communities to provide the necessary and just transition to renewable energy. The US has committed to phasing out its estimated $\$ 4$ billion in annual, inefficient fossil fuel subsidies by 2025 (Doukas 2019; Neal 2020). Recent analyses identified that regionally appropriate renewable energy is more cost effective and reliable than over $75 \%$ of the current US coal fleet (Neal 2020). The policy options below detail ways to expand renewable energy development by transitioning federal subsidies away from the coal industry and towards the development of renewable energy in current and former coal 
communities. Specifically, land reclamation, job retraining, and community support chart a sustainable path towards phasing out coal and creating practical economic opportunities in affected communities.

\section{i. Land reclamation}

The federal government would encourage land reclamation by providing subsidies to renewable energy companies that build their facilities on abandoned mine sites. In turn, these companies would accept the burden of reclamation. Additionally, the Office of Surface Mining Reclamation and Enforcement (OSMRE), within the Department of Interior, would strengthen the Abandoned Mine Land Reclamation Program, which was enacted in 1977 to promote mine cleanup using funds collected from coal companies. However, this program does not strictly enforce deadlines for mine cleanup, leading to many perpetually abandoned mines. Concrete changes could improve this program, such as expanding the OSMRE database of abandoned mines (Office of Surface Mining Reclamation and Enforcement 2020), extending fee collection past September 2021, and requiring stricter timelines and penalties for future reclamation.

Pro

Reclamation creates jobs such as filling in underground tunnels and open mine pits (Erickson 2020), replacing topsoil, and removing infrastructure (Vanderpool 2020). It is therefore a logical job progression for coal miners, as retraining and relocation are not required (Western Org. of Resource Councils 2020). Available, skilled workers combined with an updated database of abandoned coal sites would lower the barrier for industry to launch reclamation projects. With the support of federal aid, this transition would create new investment opportunities, reemploy former coal workers, and alleviate financial and health burdens on the affected community. Specific timelines and penalties would make this policy more enforceable than previous policies.

\section{Con}

Without an explicit plan for retraining in the newly operational renewable energy sector, land reclamation would result in healthier land and communities, but only temporary jobs. Additionally, after currently active mines are closed and land reclamation is complete, the surrounding community would lack a local energy source without additional infrastructure added. The government can provide subsidies but cannot guarantee that private sector industries would participate.

\section{ii. Job retraining}

The federal government would subsidize private renewable energy companies to expand operations at closed coal power plant sites, hire existing community members, and provide job retraining at their power plants. Because most coal miners have strong ties to their communities and do not wish to relocate (Pai et al. 2020), clean energy companies must be incentivized to bring training programs to the workers, free of cost for both the company and the trainee. Coal miners can be retrained for other manual labor, such as maintaining wind turbines or installing solar panels. Companies like Goldwind Americas, CSX, and Lockheed Martin are pioneering paid training programs for miners and guaranteeing their employment upon completion (Marston 2018; Bottino 2018). These programs can serve as a successful model but must be expanded and reliably funded to continue mutually beneficial and productive training across the country.

\section{Pro}

The majority of coal mining areas in the US are suitable for solar and/or wind power (Pai et al. 2020), so former coal workers can be reemployed in regionally appropriate clean energy jobs with similar skill requirements, competitive salary, and benefits (Louie and Pearce 2016). Job retraining for clean energy jobs is a sustainable approach for assisting coal communities, as an influx of jobs would stimulate the economy, and those jobs would be permanent.

\section{Con}

Job retraining programs would take time to develop and scale, leaving communities unsupported immediately following power plant closure. Former coal workers may be reluctant to change career paths.

\section{iii. Community support}

The Interagency Working Group would create a comprehensive climate and energy policy outlining timelines to phase out coal while supporting financially dependent communities during the transition. To provide direct community support, the Interagency Working Group would expand funding 
for POWER+ and Assistance for Coal Communities. These funds could be designated for job retraining, career support, and direct economic aid to those affected by the transition to renewable energy. Remaining funds can be put towards developing and distributing educational and technological resources to the communities to increase accessibility and awareness.

Pro

Published timelines for phasing-out coal would reduce uncertainty, help communities plan for the transition, and provide a strong cue from the government that would encourage private sector investment in renewable energy. Direct aid to coal communities would reduce economic hardship during the time-lag between coal mine or plant closure and renewable energy replacement. Community hesitation is still a considerable barrier to the phase-out of coal, and economic aid and community outreach would increase community confidence in the transition.

\section{Con}

Interagency policy making is time consuming, and these communities are in need of immediate support. This aid would provide short-term economic relief, but the long-term economic revitalization relies on the successful replacement of the coal industry by renewable energy. Additionally, the loss of coal energy without replacement by renewable energy would strain the existing electric grid.

\section{References}

Anderson, Charles. 2007. H. C. R. No. 43: Urging the Texas Commission on Environmental Quality to impose a 180-day moratorium on applications for pulverized coal-fired power plant permits. Legislative Reference Library of Texas. https://capitol.texas.gov/tlodocs/80R/billtext/p df/HC00043I.pdf.

Beyer, Lee. 2016. SB 1547 - Elimination of Coal from Energy Supply. Oregon Legislative Assembly. https://olis.leg.state.or.us/liz/2016R1/Downloa ds/MeasureDocument/SB1547.

Bottino, Tiziana. 2018. "Retraining Programs for Coal Workers in Transition: Lessons from Appalachia." PhD diss., Johns Hopkins University.

\section{Policy recommendation}

We recommend that the Interagency Working Group implement policy that includes a combination of land reclamation, job retraining, and community support through expansion of POWER+. All three strategies are reliant on each other, and when implemented in tandem can provide holistic, long-term support for coal communities: 1) Land reclamation would repurpose mined land for more economically viable renewables, 2) job retraining would ensure the involvement of community members and restore permanent job opportunities, and 3) community support would ease the burden of the transition by providing short- and long-term financial support. Through this recommendation, the Interagency Working Group would shift federal subsidies for coal companies to renewable energy companies that expand operations in coal communities. These companies would work with the government to fund and expand land reclamation, while the government streamlines private purchasing of abandoned mines through the improved database of shut-down mines. Once the land is reclaimed, the companies would receive subsidies to offer job retraining programs, providing continued employment opportunities at all skill levels. Federal aid towards these goals would create new investment opportunities, reemployment for former coal workers, and remove undue financial and health burdens on the affected community.

California Energy Commission. 2020. Emission Performance Standard - SB 1368. In California Energy Commission. California Energy Commission. www.energy.ca.gov/rules-andregulations/energy-suppliersreporting/emission-performance-standard-sb$\underline{1368}$.

Cartwright, Matt. 2021. H.R.1733 - 117th Congress (20212022): RECLAIM Act of 2021. Washington, DC: U.S. House of Representatives, 117th Congress. https://www.congress.gov/bill/117thcongress/house-bill/1733.

Cecire, Michael H. 2019. The POWER Initiative: Energy Transition as Economic Development. Congressional Research Service. https://crsreports.congress.gov/product/pdf/R/ R46015. 
Dennis, Brady and Mufson, Steven. 2019. "In Small Towns across the Nation, the Death of a Coal Plant Leaves an Unmistakable Void." The Washington Post. www.washingtonpost.com/national/healthscience/thats-what-happens-when-a-big-plantshuts-down-in-a-smalltown/2019/03/28/57d62700-4a57-11e9-966300ac73f49662 story.html.

Doukas, Alex and Ipek Gençsü. 2019. "G20 coal subsidies: United States." Overseas Development Institute. Last modified June 25, 2019. http://cdn.odi.org/media/documents/12751.pdf.

Duckworth, Tammy. 2020. S.4306 - 116th Congress (20192020): Marshall Plan for Coal Country Act of 2020. Washington, DC: U.S House of Representatives, 116th Congress. www.congress.gov/bill/116thcongress/senate-bill/4306.

Office of Surface Mining Reclamation and Enforcement. 2020. Office of Surface Mining Reclamation and Enforcement. US Department of Interior. https://amlis.osmre.gov/Map.aspx.

Economic Development Administration. 2017. Fiscal Year 2017 Annual Report. Washington, DC: EDA, U.S. Department of Commerce. www.eda.gov/files/annual-reports/fy2017/EDAFY2017-Annual-Report-full.pdf.

Environmental Protection Agency. 2015. Gold King Mine Watershed Fact Sheet. Washington, DC: U.S. Environmental Protection Agency. https://www.epa.gov/sites/production/files/20 $\underline{15-}$

$\underline{08 / d o c u m e n t s / g o l d k i n g m i n e w a t e r s h e d f a c t s h e e t ~}$ background.pdf.

Erickson, Camille. 2020. "Wyoming's Program to Clean up Abandoned Mines Offers Some Hope to Local Economies." Casper Star-Tribune, October 4, 2020. https://trib.com/business/energy/wyomingsprogram-to-clean-up-abandoned-mines-offerssome-hope-to-local-economies/article fd2b5f305e15-5db2-8158-184024e18dce.html.

Fritsch, David. 2019. "U.S. coal production employment has fallen 42\% since 2011." U.S. Energy Information Administration. Published October 11, 2019. https://www.eia.gov/todayinenergy/detail.php?i $\mathrm{d}=42275$.

Grijalva, Raul M. 2020. H.R.5435 - 116th Congress (20192020): American Public Lands and Waters Climate Solution Act of 2019. Washington, DC: U.S. House of Representatives, 116th Congress. www.congress.gov/bill/116th-congress/housebill/5435.

Grijalva, Raul M. 2021. H.R.2021 - 117th Congress (20212022): Environmental Justice for All Act. Washington, DC: U.S. House of Representatives, 117th Congress. https://www.congress.gov/bill/117thcongress/house-bill/2021.
Gross, Samantha. 2020. "What is the Trump administration's track record on the environment?" Brookings Institution, August 4, 2020.

https://www.brookings.edu/policy2020/votervi tal/what-is-the-trump-administrations-trackrecord-on-the-environment/.

Haynes, Martina Jackson, Jacqui Patterson, Larissa Johnson. 2012. Coal Blooded Action Toolkit. Baltimore, MD: NAACP Environmental and Climate Justice Program, 2012. https://www.naacp.org/wpcontent/uploads/2016/04/Coal Blooded Action Toolkit FINAL FINAL.pdf.

Humphreys, Joshua, Becky Johnson, Kristin Lang, David Roswell, and Sandra Korn. 2014. Fossil-Free Investment for a Just Appalachian Transition: Obstacles and Opportunities. Berea, Kentucky: Croatan Institute. https://communitywealth.org/sites/clone.communitywealth.org/files/downloads/paper-humphreyset-al.pdf.

Jolley, G. Jason, Christelle Khalaf, Gilbert Michaud, and Austin M. Sandler. 2019. "The economic, fiscal, and workforce impacts of coal-fired power plant closures in Appalachian Ohio." Regional Science Policy and Practice, 11, no. 2: 403-422. https://doi.org/10.1111/rsp3.12191.

Louie, Edward P., Joshua M. Pearce. 2016. "Retraining Investment for US Transition from Coal to Solar Photovoltaic Employment." Energy Economics 57: 295-302.

https://doi.org/10.1016/i.eneco.2016.05.016.

Marston, Jim. 2018. "Why These Companies Turn to Coal Country for Skilled Workers." Environmental Defense Fund, EDF Voices Blog, May 8, 2018. https://www.edf.org/blog/2018/05/08/whythese-companies-turn-coal-country-skilledworkers.

McConnell, Mitch. 2017. RECLAIM Act of 2017. S.728. Washington, DC: U.S. House of Representatives, https://www.congress.gov/bill/115thcongress/senate-bill/728.

Milman, Oliver. 2020. "'My Friends Were Lied to': Will Coal Miners Stand by Trump as Jobs Disappear?" The Guardian. September 24, 2020. https://www.theguardian.com/usnews/2020/sep/24/donald-trump-coal-minersus-election.

Neal, Abby. 2020. "Issue Brief: How Coal Country Can Adapt to the Energy Transition." Environmental and Energy Study Institute (EESI), November 10, 2020. www.eesi.org/papers/view/issue-briefhow-coal-country-can-adapt-to-the-energytransition. 
O'Donoghue, Amy. 2020. "Abandoned mines' threat to drinking water remains unknown." Associated Press, August 29, 2020. https://apnews.com/article/2f7237e90df9f531f 3deb64f6a0d8d54.

Office of Surface Mine Reclamation and Enforcement (OSMRE). 2019. "Laws, Regulation, and Guidance: Surface Mining Control and Reclamation Act (SMCRA)." https://www.osmre.gov/lrg.shtm.

Pai, Sandeep, Hisham Zerriffi, Jessica Jewell, and Jaivik Pathak. 2020. "Solar Has Greater TechnoEconomic Resource Suitability than Wind for Replacing Coal Mining Jobs." Environmental Research Letters 15, no. 3 (March): 034065, 1-13. https://doi.org/10.1088/1748-9326/ab6c6d.

Palacios, Kim. 2020. "U.S. coal consumption continues to decline across all sectors." Today in Energy, June 16, 2020. https://www.eia.gov/todayinenergy/detail.php?i $\mathrm{d}=44115$.

Sainato, Michael. 2020. "The Collapse of Coal: Pandemic Accelerates Appalachia Job Losses." The Guardian, May 29, 2020. https://www.theguardian.com/usnews/2020/may/29/coal-miners-coronavirusjob-losses.
Skibell, Arianna. 2020. "Thousands of coal workers lost jobs. Where will they go?" E\&E News, June, 24, 2020. https://www.eenews.net/stories/1063442773. Vanderpool, Tim. 2020. "After the Local Coal Mine Shuts Down, These Navajo and Hopi Communities Seek a Just Transition." Natural Resources Defense Council, October 20, 2020. www.nrdc.org/stories/after-local-coal-mineshuts-down-these-navajo-and-hopicommunities-seek-just-transition.

Western Organization of Resource Councils. 2020. "Coal Mine Cleanup Works: A Look at the Potential Employment Needs for Mine Reclamation in the West." Last modified October 2020. http://www.worc.org/media/Reclamation-JobsReport-FINAL Nov-2020.pdf.

White House. 2021. "Executive Order on Tackling the Climate Crisis at Home and Abroad." Last modified January 27, 2021. https://www.whitehouse.gov/briefingroom/presidentialactions/2021/01/27/executive-order-ontackling-the-climate-crisis-at-home-and-abroad/

Grace E. Chesmore is a Ph.D. candidate in physics at the University of Chicago, where she works as an experimental cosmologist. She received her M.S. in physics from the University of Michigan and a B.A. in physics from Santa Clara University. She serves as the Vice President of the Science Policy Group at the University of Chicago and works to connect Illinois legislators with science experts for more informed policymaking.

Rachel L. Starr is a Ph.D. candidate in Chemistry at Columbia University, focusing on making and using a variety of functional nanomaterials for a range of applications, including drug delivery and electronics. After graduation, she plans to work in the science policy space on clean energy/climate change solutions. She holds a B.A. in Chemistry from Barnard College.

Rebecca Van Hoeck is a Ph.D. candidate in the Biology Department at the University of North Carolina at Chapel Hill. Her research uses marine soundscapes to ask a variety of ecological questions, including how fishery populations may interact with offshore wind energy development. She serves as a Co-President of the UNC Science Policy Advocacy Group and holds a B.S. in Marine Science and Biology from the University of Tampa.

Meredith L. Ward holds an M.S. in chemistry from the University of Massachusetts, Boston, and a B.S. in chemistry from the University of Texas at Austin. She currently works as an analytical chemist in the cannabis industry in Massachusetts. She is also interested in environmental justice, air pollution, and energy issues. 